\title{
Does Safeguards Need Saving? Lessons from the Ukraine-Passenger Cars Dispute
}

\author{
AREVIK GNUTZMANN-MKRTCHYAN * \\ Leibniz University of Hanover \\ SIMON LESTER * * \\ Cato Institute
}

\begin{abstract}
The Panel Report in Ukraine-Passenger Cars provides an opportunity to revisit an old debate over the role of safeguard measures in the WTO. With regard to the legal findings, the Panel followed the established jurisprudence in this area, and found a number of violations of the Safeguards Agreement. With regard to the economics, we delve more deeply into the economic and political background of the safeguards investigation. Ukraine was hit by the economic crisis shortly after its WTO accession that significantly liberalized import tariffs on passenger cars. Next, we offer a de novo look at the injury and causation issues in this case, and discuss the challenges of an industry reliant on offshored production that sees a safeguard as a mechanism to attract foreign direct investment (FDI) for production. We conclude with an assessment of the operation of the WTO's safeguards regime, along with some tentative suggestions for reform. Overall, our examination of the economic analysis by the investigating authority and the legal review by the WTO Panel raises questions about particular aspects of the domestic and WTO processes, but concludes that the system worked well in this case.
\end{abstract}

\section{Introduction}

Safeguards is a long-standing mechanism by which GATT Contracting Parties, and now WTO Members, can deviate from their normal free trade obligations, and impose tariffs to protect a domestic industry. Importantly, and in contrast to the two other so-called 'trade remedies', safeguards is not a response to 'unfair' trade. There are no allegations of unfairness in a safeguards proceeding. Rather, the claim is simply that there was an unexpected surge in imports, which caused economic harm to the domestic industry, and temporary protection is justified.

While safeguards appears to go against the trade liberalization goals of the GATT/WTO, the idea is that such protections make it possible for governments

\footnotetext{
*Email: mkrtchyan@mak.uni-hannover.de

**Email: slester@cato.org
} 
to liberalize. If they could not offer domestic industry these protections, the argument goes, those industries would never agree to liberalization in the first place.

But what if the safeguards protections do not actually work under the constraints imposed by the WTO? What if it becomes almost impossible to use the safeguards process? This concern arose after the first few WTO disputes over safeguards measures.

To date, there have been ten WTO dispute proceedings involving claims under the Safeguards Agreement. In all ten cases, the safeguards measure at issue was found in violation of that Agreement. Some early commentary on the Safeguards Agreement suggested that the inability to defend safeguards measures at the WTO indicated a problem with the operation of the Agreement. The UkrainePassenger Cars Panel Report ${ }^{1}$ provides an opportunity to assess the current state of the Agreement. Is WTO review of domestic safeguards measures too strict? Or, on the other hand, is it simply a necessary check on possible abuses by domestic authorities?

In this case review, we begin with an examination of the safeguard measure itself and the economic background of the safeguard investigation. In this regard, we consider various issues related to Ukraine's WTO accession, the global economic crisis, and the political economy of the safeguard measure, before turning to the Panel's findings on the legality of that measure.

First, we look at the macroeconomic shocks to the Ukrainian economy prior to the safeguard investigation. The safeguard investigation came three years after Ukraine's WTO accession in 2008 liberalized import tariffs for passenger cars from $25 \%$ to $10 \%$. Bown and $\mathrm{Wu}$ (2014) suggest that safeguard and antidumping measures frequently arise following a new trade agreement as a result of market shocks brought by the agreement. At the same time, just months after the accession the country was hit by the global economic crisis that sharply reduced credit availability and consumer demand for passenger cars. Our analysis continues with a discussion of varying political positions surrounding Ukraine's safeguard investigation. Part of the political elite considered the safeguard measures necessary to prevent a serious injury to the domestic industry while the other part stressed the negative impact on the auto-importing businesses and prices. As a result, the findings of the investigation were published one year after the decision was made. Next, we analyze Ukraine's passenger car market in the post-Soviet period and during the period relevant for the safeguard investigation, before turning to a brief overview of the Panel's findings. Overall, the Panel found Ukraine's measure was violating a number of provisions of the Safeguards Agreement.

We then offer a de novo review of the measure, by delving into the background of the measure, including assessment of increased imports, and injury and causation

1 Panel Report, Ukraine-Definitive Safeguard Measures on Certain Passenger Cars, WT/DS468/R, adopted 20 July 2015. 
issues in this case. Then we discuss some of the implications from the case. First, the procedural failures of the investigation demonstrate the challenges that developing countries still face in the application of multilateral trade rules. Second, the case raises new questions about the challenges of an industry reliant on off-shored production. The Ukrainian automobile firms abandoned local brands and were producing cars under foreign firms' assembling and manufacturing licenses. We hypothesize that for such an industry the assessment of causal impact of increased imports versus domestic supply shift can be quite different from a more traditional domestic industry as the domestic supply is ultimately determined by foreign investment and manufacturing contracts.

We conclude with an assessment of the operation of the WTO's safeguards regime, along with some tentative suggestions for reform, to the extent that people continue to believe that reform is needed.

\section{Economic background and safeguard investigation}

\subsection{WTO accession, crisis and political economy of Ukraine's safeguard investigation}

In 2008 and 2009, the Ukrainian car market was hit by two important events. First, in May 2008, Ukraine joined the WTO. As a result of the WTO accession, car import tariffs dropped from $25 \%$ to $10 \%$ and the prohibition on importing used cars older than eight years was lifted (Ernst and Young, 2016). Second, the financial crisis and credit crunch hit Ukraine in 2009, when only about $5 \%$ of cars were purchased with credit compared with about $50 \%$ in 2008 (AUTOConsulting, 2009b; Focus, 2008). Demand for new cars dropped by $74 \%$ from 2008 to 2009 , due to falling incomes, lack of credit opportunities, and economic uncertainty. The Ukrainian economy was greatly affected by the crisis, and the currency depreciated substantially. Sharp economic contraction was already evident by early in 2009. In response, the Parliament passed a law, overriding a presidential veto that increased the import tariffs for all goods except for 'critical imports' by $13 \%$ in March 2009. The measure was removed in May 2009 for most goods, and in September for refrigerators and motor cars (WTO, 2016; CMS, 2009).

In its request for a safeguard investigation in 2011, the industry association UkrAutoprom, representing domestic producers ZAZ, KrASZ, and Eurocar (Bogdan joined later), mentioned that the share of imported cars in total sales during the 2008-2010 period had increased by $16 \%$. The capacity utilization of Ukrainian factories was at $20 \%$ and the number of employees decreased by $70 \%$. Representatives of the industry association claimed that the safeguard measures would give incentives for FDI that would lead to the opening of new factories. UkrAvtoprom had previously obtained protection against automobile imports from Russia between 2001 and 2006, first through a 31.7\% duty and then through quotas. As a result of the measures, VAZ started car manufacturing in 
Ukraine. Petr Poroshenko, then the Minister of Economy, announced in early June 2012 that the safeguard investigation had come to a conclusion and that Ukraine had good reasons to protect the market. The results of the investigation, however, were not made public. The minister justified the need for protection, comparing Russian import tariffs of $20-25 \%$ with Ukrainian tariffs at $10 \%$ and mentioning subsidies received by European automobile producers. He also said the protection is needed due to 12,000 jobs lost because of the decline in Ukrainian car production in 2009 (AUTO-Consulting, 2012c; Zerkalo Nedeli, 2012).

The investigative authority (Interdepartmental Committee for International Trade) found that the share of imported products in the total amount of products sold domestically increased by $37.9 \%$ in 2010 relative to 2008 , although in absolute terms imported products fell by $71 \%$. The domestic production in Ukraine fell by $76.9 \%$ over the same period, the largest drop in the world, and domestic sales fell by $86.3 \%$. The Committee pointed to the increase in the import share of cars originating from Turkey, South Korea, Romania, and Germany in 2010 relative to 2008. According to the Committee, the number of workers in domestic car manufacturing fell by $51.6 \%$ and operational profits fell by $89.9 \%$. The Committee concluded that increased imports had led to the displacement of the domestic producers from the home market and threatened serious injury to the industry.

The introduction of the safeguard measure was met with resistance within Ukraine. Although the investigative committee came to its conclusions by the 28 May 2012, the decision was not circulated until 14 March 2013. Lobbying from the industry association on one side, and the importers association, on the other side, could be behind the delay. The association of car importers and dealers was vocal about the potential negative impacts of the measure. Furthermore, Viktor Janukovich Jr, a Ukrainian MP and vice-president of the national automobile club, strongly criticized imposing the measures, suggesting it would not help the industry, would dampen the budget due to lower import supply, and could lead to retaliation through the WTO (AUTO-Consulting, 2012d). The role of these political economy factors was exacerbated by the reports that Poroshenko's business reach involved ownership of the car production company Bogdan and Lutsk (AUTO-Consulting, 2012a; Golovnev, 2014).

Table 1 presents a timeline of the events from the initiation of the investigation in 2011 until the revocation of the safeguard measure in September 2015.

\subsection{Automobile production in post-Soviet Ukraine}

At the end of the 1980s, four companies produced cars and trucks in the Ukraine. The most important car manufacturer was ZAZ (which was one of the domestic firms that requested the safeguard investigation), known for its relatively cheap, small-sized model Zaporozhets that had been very popular in the USSR. During Soviet times, the market was exclusively supplied by cars produced in the USSR, 
Table 1. Timeline of events related to the safeguard measure

\begin{tabular}{ll}
\hline \hline Date & Event \\
\hline 30 June 2011 & Initiation of safeguard investigation \\
28 April 2012 & Safeguard investigation is concluded \\
14 March 2013 & Findings of the safeguard investigation are published \\
14 April 2013 & Safeguard measure comes into force \\
30 October 2013 & Japan files a request for consultations at the WTO \\
14 April 2014 & Ukraine reduces the safeguard duty levels \\
26 March 2014 & A Panel is established at the WTO \\
26 June 2015 & Panel Report is published \\
30 September 2015 & Safeguard measure is revoked \\
\hline
\end{tabular}

in particular Russian SFSR and Ukrainian SSR. In 1994, ZAZ was privatized, although the state continued to hold $86 \%$ of the company. ZAZ launched a new model Tavria in 1995, but sales fell continuously over time. The production of ZAZ declined from 156,000 cars in 1991 to negligible levels by 1997. The low quality of the Tavria model and a relatively high price were key to the falling demand.

ZAZ initiated a joint venture with Daewoo in 1998 to help it stay afloat. As part of the deal, the Ukrainian government increased import tariffs on cars from $30 \%$ to $60 \%$. Also, Daewoo was granted special privileges, such as importing parts dutyfree. After the first year, the joint venture was already performing below the expectations of both parties. Only minimal assembly was done in Ukraine, as practically all assembled cars were coming from South Korea. For its part, Daewoo was unhappy with the high number of imports of used cars, which undercut its sales. Used cars constituted a large majority of all car sales, and importers of used cars found various loopholes to avoid paying the hefty import duties. The problems of the joint venture with Daewoo are similar to challenges of the Ukrainian automobile industry in 2009. Among the main reasons for the failure of the joint venture were the economic crisis of 1998-1999 that affected internal market demand, the low productivity of the production in Ukraine, and competition with other countries hosting Daewoo production facilities (Romania, Poland, and Uzbekistan).

By contrast, an assembly partnership of Ukrainian car factories with the Russian company AvtoVAZ was long lasting. Before 1999, AvtoVAZ only exported assembled cars, but after 1999 AvtoVAZ started supplying parts and components to Ukrainian factories to assemble cars. When Ukraine imposed a preliminary antidumping duty of $31.7 \%$ on car imports from Russia in August 2002, the measure had an instantaneous effect. Within four months of the measure coming into force, the market share of AvtoVAZ fell from 54\% to 37\% (Ukrayinska Pravda, 2003). Shortly afterwards the duty was revoked while an import quota was introduced. 
These measures led to a further expansion of the AvtoVAZ's Lada car assembly in Ukraine. Success of these trade restrictive measures targeted at encouraging Russian car producers to assemble in Ukraine was a relevant motivator for imposing the safeguard measures in 2013.

\subsection{Ukraine's passenger car market}

The economic downturn that the post-Soviet countries were experiencing up until the 2000s eventually gave way to more rapid growth. From 2000 to 2008, Ukraine's GDP increased by 71\% (World Bank, 2015). In addition, the low car density of 106.76 cars per 1,000 people in 2000 increased to 138.22 per 1,000 people in 2008 (HumanProgress.org, 2014). Soaring incomes, demand, and credit availability had a positive impact on car sales, which grew at about $30 \%$ annually. By 2008, Ukraine was an important market for passenger cars as the seventh largest market in Europe by the number of cars sold and by growth potential (AUTO-Consulting, 2009a).

Figure 1 shows the quantity of car sales, domestic production, imports, and exports from 2006 to 2013 relative to the amount in 2008. The passenger car market in Ukraine was rapidly growing and all factors were improving between 2005 and 2008. However, the market crashed in 2009 as the country was hit by the global economic crisis that sharply reduced credit availability and consumer demand for passenger cars. Sales of both locally produced and imported cars plummeted: only about 162,000 cars were sold in 2009 compared to 623,000 in 2008. In the period from 2008 to 2009, imports and domestic production fell at an almost equal rate. However total imports showed a recovery from 2009 to 2010 while the domestic production stagnated, which was probably related to the liberalization of import duties on passenger cars.

Figure 2 shows Ukraine's import values of passenger cars for the five largest exporters and the rest of the world. The main passenger car exporters to Ukraine in the 2008-2010 period, analyzed in the safeguard investigation, were Japan, Russia, China, Germany, and South Korea. Japan was the largest exporter during the period and more than doubled exports to Ukraine from 2007 to 2008. The sharp and sudden increase was possibly driven by optimistic predictions about market development.

Japan's role as the largest exporter with quickly rising importance in the Ukrainian market could explain why Japan initiated the litigation, although the safeguard measure affected all exporters. Indeed, as Bown and McCulloch (2003) discuss, safeguard measures have a disproportionate negative effect on the largest and fastest growing exporters. The Japanese delegation at the WTO mentioned, in its arguments against the safeguard measure, that Ukraine's passenger car imports in 2010 were actually $71.5 \%$ lower than the 2009 levels. Japan was claiming that its car exports to Ukraine dropped even more: from 51,600 cars in 2008 to 9,000 cars in 2010, that is, by $82.5 \%$. Overall, trends in Figure 2 
Figure 1. Passenger car market in Ukraine (index, $2008=1$ )

1.2

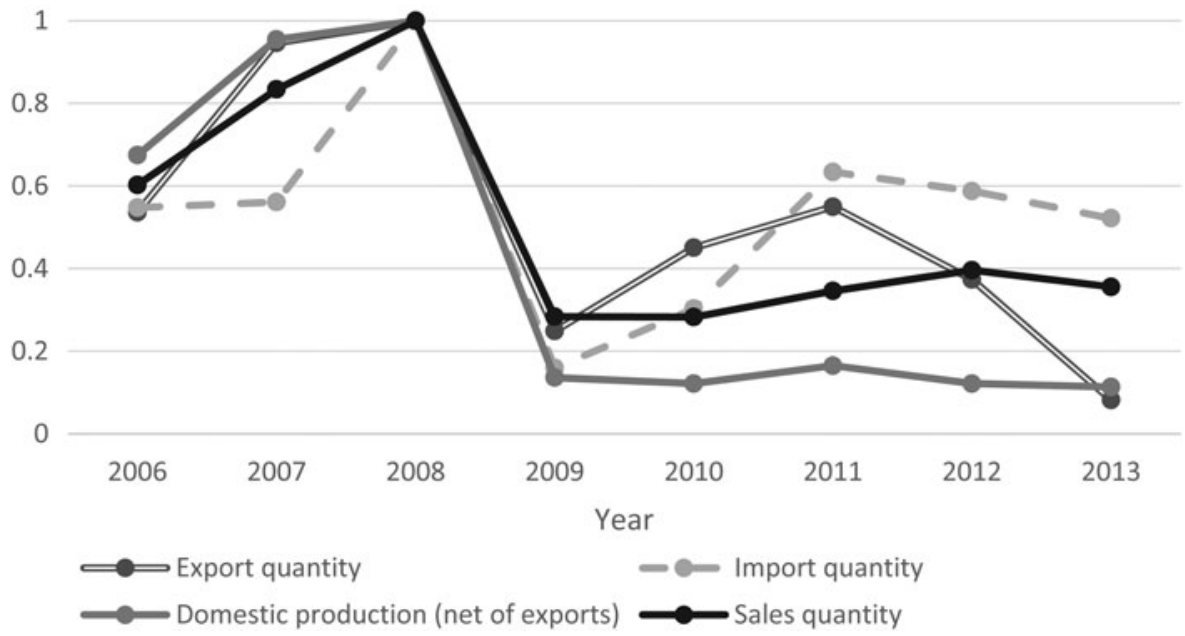

Source: UN COMTRADE, International Organization of Motor Vehicle Manufacturers.

Figure 2. Import value of passenger cars of Ukraine by exporters, US dollars

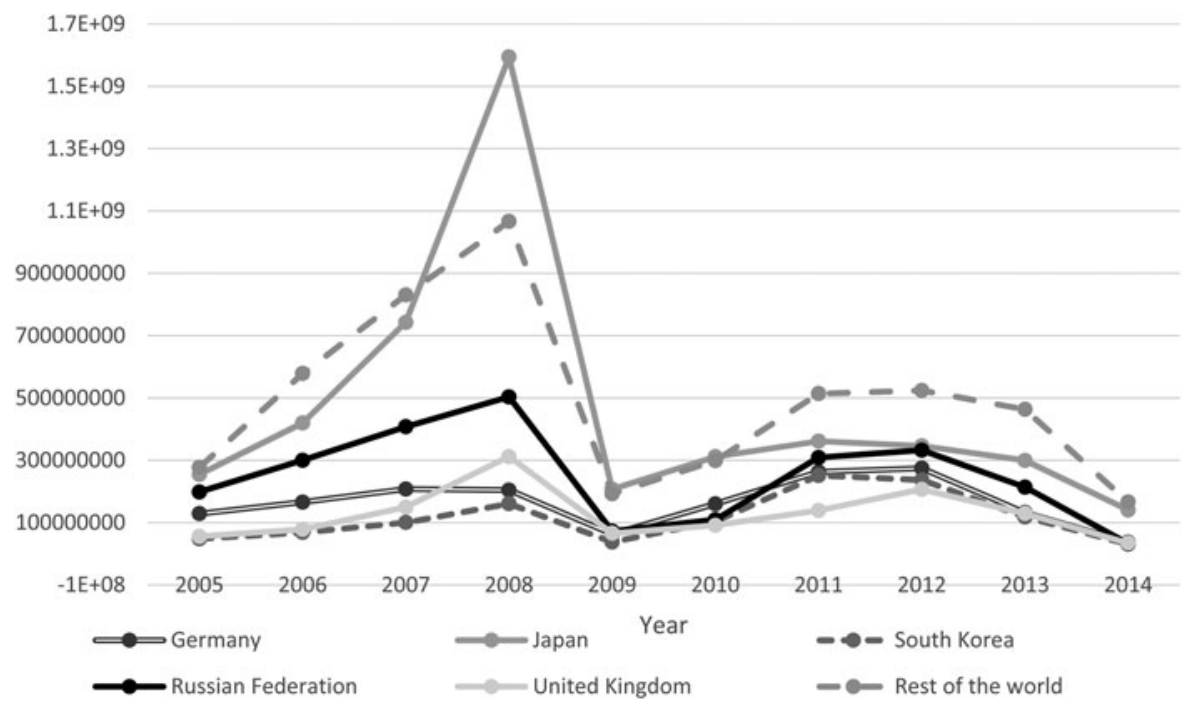

Source: Prepared by authors using data from UN COMTRADE, Harmonized System codes 870322 and 870323. 
support the Japanese position that the imports were sharply falling during the analyzed period.

\section{Analysis of the Panel's findings - Ukraine-Passenger Cars}

There are two stages for safeguard measures. First, through a domestic legal process, a government agency must decide whether to impose a measure. Second, after a measure has been imposed, WTO Members may challenge that measure in WTO dispute settlement. In this section, we consider the second stage in relation to the measure at issue here.

The analysis of any WTO dispute must begin with the specific government measure(s) at issue. Here, the measure was the definitive safeguard duty imposed by Ukraine on imports of certain passenger cars, and the investigation that led to the imposition of this measure.

The safeguard measure took the form of special tariff duties imposed at different rates, differentiated by engine volumes, as follows: $6.46 \%$ for passenger cars with an engine volume of $1000 \mathrm{~cm} 3-1500 \mathrm{~cm} 3$ (UKTZED ${ }^{2}$ code 870322 1000) and $12.95 \%$ for passenger cars with an engine volume of $1500 \mathrm{~cm} 3-2200 \mathrm{~cm} 3$ (UKTZED code 870323 1910)). The safeguard measure was to be progressively liberalized in accordance with a schedule based on 12 and 24 months from the day of initial application of the measure, with duties reduced to $4.31 \%$ and $2.15 \%$ for the first engine category and $8.63 \%$ and $4.32 \%$ for the second category. ${ }^{3}$

In terms of the legal claims, for the most part, this dispute dealt with issues similar to those raised in other safeguards disputes. In this section, we provide a brief overview of the most important Panel findings.

To begin, an overarching issue that arises in trade remedy challenges at the WTO is the standard of review. In such cases, the WTO dispute settlement system is reviewing a domestic judicial decision, acting, in a sense, as a court of appeal. Thus, a WTO Panel is not conducting a de novo review of the issue, that is, it is not making a finding of its own as to whether, for example, increased imports have caused serious injury. Rather, it is applying a standard of review that allows it to scrutinize the domestic authority's reasoning on the issue of whether increased imports have caused serious injury.

Here, the Panel explained that its 'examination of the competent authorities' determinations [would] be based on the report published by the competent authorities'. In this regard, 'the explanations contained in the report must be 'explicit', 'clear and unambiguous', and must not 'merely imply or suggest an explanation'. 'In the event that there is no 'reasoned and adequate explanation' for the 
determination set out in the published report, the Panel has 'no option but to find that the competent authority has not performed the analysis correctly'. ${ }^{4}$

We now turn to a summary of the legal claims of the Panel Report.

\subsection{Unforeseen developments}

Turning to the legal claims, in two early decisions - see Argentina-Footwear ${ }^{5}$ and Korea-Dairy ${ }^{6}$ - the Appellate Body found that the language in GATT Article XIX:1(a) on 'unforeseen developments' and 'the effect of GATT obligations' continued to apply after the Safeguards Agreement was in effect. Applying these provisions in this case, the Panel found that Ukraine failed to make a proper determination of unforeseen developments, because 'the competent authorities in their published report identified the relative increase in imports as the unforeseen development rather than identifying and explaining any unforeseen developments that resulted in that relative increase in imports'. It also found that Ukraine failed to make a proper determination of the effect of GATT 1994 obligations, because it did not identify in its published report the effect of GATT 1994 obligations. ${ }^{7}$

The Panel then addressed the three core elements of a safeguards determination: increased imports, serious injury (here, the threat of serious injury), and causation.

\subsection{Increased imports}

With regard to the issue of increased imports, the Panel found a violation of Article 2.1 of the Safeguards Agreement on three bases. First, the Panel concluded that Ukraine acted inconsistently with Article 2.1 by failing to provide an explanation in its published report regarding how intervening trends in imports relative to domestic production supported the competent authorities' determination that there was a relative increase for the period of investigation (2008-2010). In addition, the Panel concluded that Ukraine acted inconsistently with Article 2.1 by failing to demonstrate in its published report, through reasoned explanations, that there was an increase in imports during the period of investigation that was sudden enough, sharp enough, and significant enough. Finally, Ukraine acted inconsistently with Article 2.1 - specifically the requirement that a product is being imported' in increased quantities - by applying a safeguard measure that was not based on a 'recent' increase in imports. ${ }^{8}$

To illustrate this issue more clearly, in terms of the flaws in the investigating authorities' analysis identified by the Panel, it is worth going into more depth on

4 Ibid., paras. 7.22-7.28.

5 Appellate Body Report, Argentina - Safeguard Measures on Imports of Footwear, WT/DS121/AB/R, adopted 12 January 2000, paras. 76-98.

6 Appellate Body Report, Korea - Definitive Safeguard Measure on Imports of Certain Dairy Products, WT/DS98/AB/R, adopted 12 January 2000, paras. 68-92.

7 Ibid., paras. $7.60-7.104$.

8 Ibid., paras. 7.116-7.185. 
one of these findings. The Panel had found it 'clear that, for an affirmative determination of increased imports to be consistent with Article 2.1, it is not sufficient for the competent authorities to establish an increase in imports through a simple mathematical comparison of data for the two end points marking the beginning and end of the period of investigation'. It continued, '[i]t is necessary, though still not sufficient by itself, that the competent authorities also set out in their published report a reasoned and adequate explanation concerning the development of imports between the end points, i.e. concerning the intervening trends in imports that occurred during the period of investigation'. Here, the Panel observed that 'the published report of the competent authorities contains only an end-point-toend-point comparison and analysis, finding that the import volume relative to domestic production was $37.9 \%$ higher in 2010 than in 2008'. The published report 'provides neither data nor an explanation concerning intervening trends in relative imports, and specifically, makes no reference to import volume relative to domestic production in 2009'. While Ukraine provided relevant data and analysis of intervening trends in imports in relative terms in its first written submission to the Panel, the Panel stated that 'such an ex post explanation cannot remedy the deficiency in the competent authorities' determination as set out in the Notice'. Nevertheless, finding it 'instructive to consider briefly' the data provided by Ukraine, the Panel considered that '[a] brief look at intervening trends ... reveals that the competent authorities' end-point-to-end-point analysis is not sufficient on its own to explain adequately why and how the facts of this case supported the conclusion of the competent authorities'. In response to Ukraine's argument that a more detailed analysis regarding increased imports was performed, but that analysis is confidential, the Panel stated that 'Ukraine did not explain how or why an analysis of intervening trends (as opposed to the actual import volumes) could be confidential'. ${ }^{9}$

\subsection{Serious injury to the domestic industry}

The second major issue in a safeguards determination is to assess whether serious injury to the domestic industry exists. Here, the allegation was of a 'threat' of serious injury under Article 4.2(a). In this regard, the Panel found as follows. First, it concluded that the competent authorities failed to properly evaluate, and give a reasoned explanation of, the likely development of the import market share and its likely effect on the situation of the domestic industry in the very near future; second, the competent authorities 'failed to properly evaluate and give a reasoned explanation of, the likely development of imports, either in absolute terms or relative to domestic production, and their likely effect on the situation of the domestic industry in the very near future'; third, the competent authorities 'failed to properly evaluate, and give a reasoned explanation of, the increase in 
the very near future in exports to Ukraine's market, anticipated to arise from current or imminent capacity of exporting countries to export'; and, finally, the competent authorities 'failed to properly evaluate, and give a reasoned explanation of, the likely developments in the injury factors relating directly to the situation of the domestic industry and the likely effect of these developments on the situation of the domestic industry in the very near future'. ${ }^{10}$ On this basis, the Panel concluded that Ukraine acted inconsistently with Safeguards Agreement Article 4.2(a).

\subsection{Causal impact of increased imports on injury}

Finally, the Panel turned to the issue of causation, that is, whether the increased imports were causing the serious injury. On this issue, the Panel recalled Appellate Body precedent that under Article 4.2(b), competent authorities are required 'to establish ... a genuine and substantial relationship of cause and effect', and also that 'the relationship between the movements in imports and the movements in injury factors is central to a causation analysis and determination'. Furthermore, the Panel agreed with the Panel in US-Steel Safeguards that 'upward movements in imports should normally occur at the same time as downward movements in injury factors in order for coincidence to be indicative of a causal link'. The Panel then examined the facts here, and noted evidence showing that between 2008 and 2009 imports decreased in absolute and relative terms and injury factors showed a deterioration, while between 2009 and 2010 imports increased in relative terms as compared to 2008, but some injury factors actually improved, as compared to 2008. While the Panel did not conclude from these trends that no coincidence in movements exists in this case, nonetheless, because the injury factors worsened when there was a relative decrease in imports and began to improve when there was a relative increase, Ukraine's investigating authorities 'should have addressed these movements, which seem counter to findings of coincidence and causation, and given reasoned and adequate explanations as to why a causal link nevertheless existed'. The Panel concluded that 'the competent authorities did not undertake a proper analysis of the relationship between movements in imports and movement in injury factors'. On this basis, the Panel found that the competent authorities did not demonstrate, through reasoned and adequate explanations, how the developments identified support their determination that a relative increase in imports contributed to bringing about a threat of serious injury. It thus concluded that Ukraine acted inconsistently with Article 4.2(b). ${ }^{11}$

The Panel also found a separate violation of the causation requirement on the basis that 'the competent authorities should have identified and explained in the published report, in clear and unambiguous terms, the nature and extent of

10 Ibid, paras. $7.222-7.270$.

11 Ibid., paras. 7.289-7.307. 
the injurious effects of those other factors as distinguished from injurious effects of increased imports, as well as the particular method used to separate and distinguish other causal factors'. ${ }^{12}$

\subsection{Other findings of violation}

Beyond these core Safeguards Agreement obligations, the Panel also concluded that, 'to the extent that Ukraine failed to provide adequate opportunity for prior consultations to review a proposed timetable for progressive liberalization, Ukraine cannot be said to have 'endeavored to maintain' a substantially equivalent level of concessions and other obligations, because without a proposed timetable for progressive liberalization, exporting Members such as Japan were unable to form an accurate understanding as to what might constitute a substantially equivalent level of concessions or other obligations'. Thus, the Panel concluded that Ukraine acted inconsistently with Safeguards Agreement Article 8.1 because it 'failed to Endeavour to maintain a substantially equivalent level of concessions and other obligations' ${ }^{13}$.

Finally, the Panel also found violations related to Ukraine's failure to provide proper notice during the proceedings, to publish the report promptly, and to notify the WTO's Safeguards Committee.

\section{Assessment of increased imports, injury and causation}

WTO Panels are not supposed to do a de novo reassessment of a safeguard measure. We, on the other hand, are under no such constraints. In this section, we examine some of the economic data relevant to the issues of whether the Ukrainian industry was suffering the economic harm required in order for a safeguard measure to be imposed. First, we will look at the evidence of increased imports followed by analyzing injury to the industry and causal effect of various factors.

It follows from the previous section that the Ukrainian authorities' published report was very brief and scarce on argumentation and providing evidence despite the long investigation process. Arguably, this shows the difficulties of the policymakers in developing countries to follow the investigation procedures required by the WTO. Thus, our analysis of the market does not represent Ukraine's published report arguments but what could have been present in the report. 


\subsection{Increased imports and injury to the domestic industry}

\subsubsection{Evidence of increased imports}

The Panel found that Ukraine acted inconsistently with the Article 2.1 of the Safeguards Agreement by failing to demonstrate clearly that there was a sharp, significant, and sudden increase in relative imports during the analyzed period (2008-2010). The WTO Panel criticized the investigation by the Ukrainian authorities for providing only information about the change in relative importance of imports between 2010 and 2008 but not showing trends and outcomes in 2009.

As we saw in Figures 1 and 2, both the total imports and imports from the largest exporters fell in absolute terms from 2008 to 2009 and increased from 2009 to 2010. Thus, the relevant question is whether there was a consistent increase in relative imports throughout the analyzed period. We will now present the trend of relative imports in Ukraine's passenger car market to understand whether Ukraine could have potentially met the requirements. Available data present two different pictures for 2009 depending on the definition of relative importance of imports. In this study, we applied two different methods for calculating the import penetration given the available data. Figure 3 provides the import penetration between 2005 and 2014 calculated with the two methods.

First, we can define the import penetration for a given period (year) as the share of foreign cars imported in that period in total car sales. The resulting trend from this definition is marked by a light gray line in Figure 3. However, this definition has a problem that is apparent in the case of the Ukrainian passenger car market. Import penetration, according to the first measure, sharply drops from 2008 to 2009 and then increases again from 2009 to 2010. The sharp increases and drops are connected with the difference in the time point when products are imported and the point when the products are actually sold on the market. Thus, the drop from 2008 to 2009 can simply be a result of over-importing in 2008 due to optimistic predictions before the crisis hit that led to cars that were imported in 2008 being sold in 2009. Hence, few additional imports were required in 2009.

Indeed, the jumps in 2008-2009 and 2009-2010 disappear if we look at the share of imported cars in total sales in a given year, whether the cars were imported in the same year or not. That is, we measure import penetration as 1 minus the market share of domestically produced cars. Imports are expected to be ordered longer in advance than the domestic production due to the transportation and clearance time, which can be quite long. Thus, the domestic production might respond quicker to the changes in market demand due the large shocks. Here we see that the share of foreign cars sold on the market increased from 2008 to 2009 and from 2009 to 2010 . The relative importance of imports increased from about $40 \%$ to $72 \%$ in 2009 and to $75 \%$ from 2009 to 2010 . 
Figure 3. Import penetration in passenger car market in Ukraine (HS 8703)

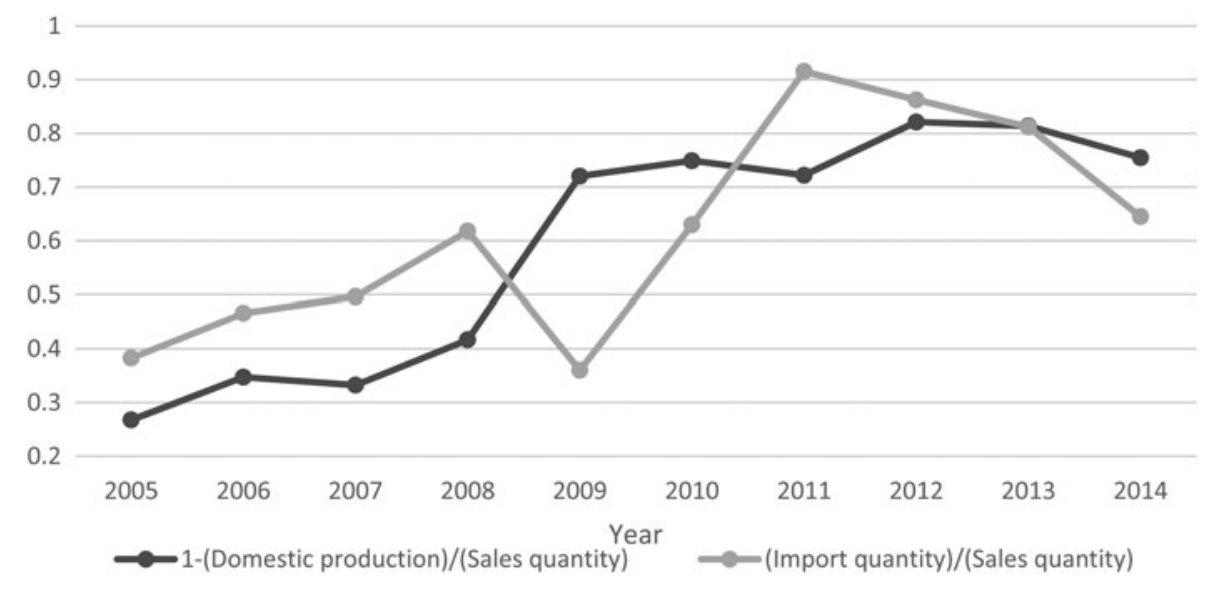

Source: Prepared by authors using data from UN COMTRADE, International Organization of Motor Vehicle Manufacturers.

\subsubsection{Evidence of threat of serious injury to the domestic industry}

With regard to injury, the WTO Panel ruled that the Ukrainian competent authorities did not demonstrate clearly that the domestic industry was under a threat of a serious injury over the analyzed period. Specifically, Ukraine did not explain what the likely development of imports would be in the near future. Below we first address the evidence of injury factors to the domestic industry and then briefly discuss how Ukraine could have explained the likely development of export capacity of exporting countries.

First, let us look at the situation of domestic industry by 2011 and possible developments. The Ukrainian car industry has not produced local brands since 2011 when the only remaining Ukrainian car, Tavria, was taken off production. But already before that the Ukrainian car manufacturing companies focused on assembling or providing complete manufacturing under the licenses of foreign car companies. The worries of the domestic manufacturers were motivated by the withdrawal of companies that were assembling in Ukraine between 2008 and 2010. In the boom years until 2008, ZAZ factories were manufacturing Opel Astra and Mercedes, while Eurocar was producing Sat, Audi, and Volkswagen cars. However, in the period from 2008 to 2010, automobile brands were withdrawing production from Ukraine. First Volkswagen terminated car manufacturing in Ukraine in the fall of 2008. Assembly by Opel and Audi stopped in 2009. As discussed in the Section 2, the Ukrainian manufacturers were requesting trade protection as a means to create an environment attractive for FDI.

Table 2 shows the only brands that continued production in Ukraine for 2011. Almost all cars produced locally (under foreign license) were under the two HS codes covered by the safeguard. Thus, Ukraine could have argued that the 
Table 2. Car production in Ukraine by car HS code, 2011-2012

\begin{tabular}{llll}
\hline \hline $\begin{array}{l}\text { Domestic } \\
\text { Firms }\end{array}$ & \multicolumn{2}{l}{ Domestically produced car models } & \\
\cline { 2 - 4 } & HS8703221000 & HS8703231910 & Neither \\
\hline Zaz & $\begin{array}{c}\text { Chery and Chevrolet (Lanos, Forza, } \\
\text { Vida) }\end{array}$ & \\
Eurocar & Skoda & Skoda & \\
KrasZ & Geely & & Ssang \\
Bogdan & & Lada-Bogdan, Hyundai & Yong \\
& & Tucson & \\
\hline \hline
\end{tabular}

Source: Inputs collected from http://ukrmach.dp.ua/2012/05/29/ukraina-komu-vygodny-specposhliny-nainomarki.html.

withdrawal of a number of brands producing in Ukraine meant that it was unlikely that the industry would recover in the near future. The safeguard measure then could provide a necessary environment for profitable production of the remaining brands after the shock of the global crisis and sharp import tariff liberalization.

Next, to assess how significant was the threat of serious injury to the domestic industry, we compare Ukraine's passenger car production with that of other countries.

One relevant comparison group is other Eastern European countries likely to have a similar economic environment. Figure 4 compares the passenger car production from 2006 to 2012 relative to the production quantity in 2008 for five Eastern European EU member states (Romania, Hungary, Slovakia, Slovenia, and Poland) and three non-members (Ukraine, Russia, and Serbia) for which we have production data for the analyzed period.

The development of Ukrainian car production before 2008 follows a very similar trend to each of the other countries. However, Ukraine had the largest production drop from 2008 to 2009 and smallest recovery from 2009 to 2010. Given that all the countries in the group are in a competition with Ukraine for attracting car manufacturers, Ukraine could have argued that the developments from 2008 to 2010 made its industry recovery unlikely while some closely located countries were increasing their production over the same period.

The second relevant group for assessing the injury includes countries that saw the largest decreases in the passenger car production during the analyzed period. Figure 5 presents the production trends for five countries with the worst fall in production (Ukraine is among them) and the total for all countries in the world. In fact, South Korea and Japan are also among the largest exporters to Ukraine. All countries saw a similarly drastic fall in production between 2008 and 2010. The production in Ukraine and Thailand fell very suddenly from 2008 to 2009 while the production of Finland, South Korea, and Japan a bit more modestly from 2008 
Figure 4. Production quantity of passenger cars of certain countries (index, $2008=1$ )

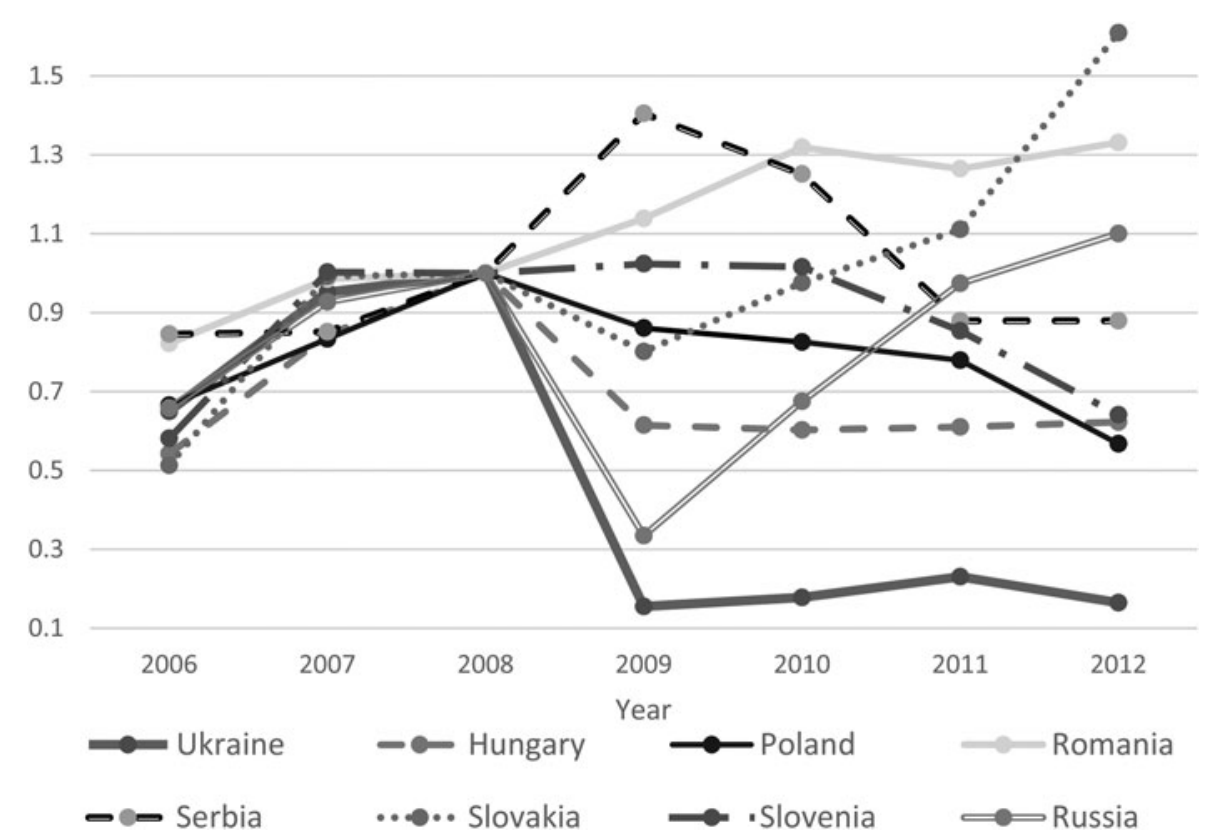

Source: Prepared by authors using data from International Organization of Motor Vehicle Manufacturers.

to 2009 with a continued fall from 2009 to 2010. At the same time, South Korea and Japan showed similarly sharp recovery by 2011. In conclusion, Ukraine had one of the worst declines in production worldwide and its slow recovery was matched only by Finland. Furthermore, two large exporters to Ukraine were also in the group of those exporters most hit after 2008 and yet they managed a much stronger recovery after 2010. Because world car production was recovering after 2010, it could also be argued that these countries also experienced an increase in their export capacity.

\subsection{Causal impact of various factors}

The WTO Panel ruled that the Ukrainian competent authorities failed to demonstrate that imports caused injury to the domestic industry. In this section, we attempt to shed light on the relative importance of various factors in causing injury to the domestic industry.

Here we follow Irwin (2003) by decomposing the change in the domestic car production into that arising due to a shift in market demand, foreign supply, and domestic supply so as to assess whether imports caused injury to the domestic industry. Irwin (2003) describes the differences in the attribution analysis between the US ITC and the WTO Safeguards Agreement and advocates a 
Figure 5. Production quantity of passenger cars of certain countries (index, $2008=1$ )

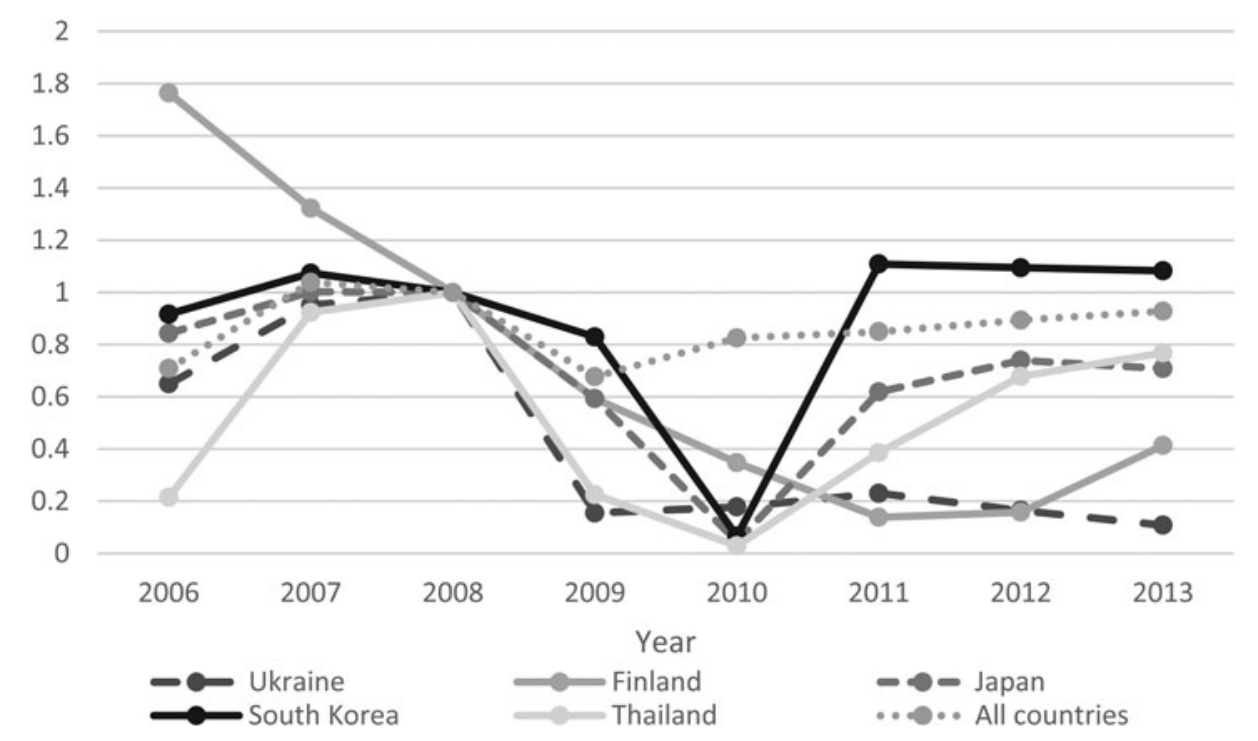

Source: Prepared by authors using data from International Organization of Motor Vehicle Manufacturers.

simple method from Kelly (1988) that provides a decomposition of the injury into various factors. If the decomposition of domestic supply change reveals that the import supply shift is the largest component, then the attribution requirement of the Safeguards Agreement is deemed to be satisfied. In line with this reasoning, we follow the method developed in Kelly (1988) to assess the role of imports in causing injury to the Ukrainian automobile industry.

Kelly (1988) develops a model with linear demand and supply functions. In its framework, soaring imports make a clear prediction on price and market demand. A shift in import supply should increase the total consumption demand and thus lead to a price drop. In such situations, the safeguard measure can protect the domestic market against import supply shocks. If instead the demand shock is the main cause of the injury, then the price should move in the same direction as the consumption demand. Falling price and consumption demand would indicate the role of a demand shock in causing the injury. Finally, a negative shift in the domestic supply curve would lead to an increase in price and imports.

We apply the version of the model where domestic and imported goods are perfect substitutes for two reasons. First, most of the domestically produced cars were in fact foreign brands that would be sold at almost the same price as the imported cars. Second, the perfect substitutes model overstates the impact of imports on domestic injury if the domestic and foreign goods are imperfect substitutes. As we will see below, increased imports are not the main injury factor even in 
the perfect substitutes' model so they would not be the main factor in the imperfect substitutes' model either.

The change in domestic supply is decomposed as follows:

$$
\begin{aligned}
\Delta S & =\frac{1}{v}[\underbrace{w_{D} e_{D} D\left(\eta \frac{\Delta P}{P}-\frac{\Delta D}{D}\right)}_{\text {Change in demand }}-\underbrace{\left(w_{M} e_{M}-\eta\right) S\left(e_{D} \frac{\Delta P}{P}-\frac{\Delta S}{S}\right)}_{\text {Change in supply }} \\
& -\underbrace{w_{D} e_{D} M\left(e_{M} \frac{\Delta P}{P}-\frac{\Delta M}{M}\right)}_{\text {Change in imports }}]
\end{aligned}
$$

where $v=\eta-w_{D} e_{D}-w_{M} e_{M}, w_{D}=\frac{S}{D}, w_{M}=\frac{M}{D}, e_{D}$ is the elasticity of domestic supply, $e_{M}$ is the elasticity of export supply, $\eta$ is the elasticity of domestic demand, $\Delta$ denotes the observed change of a variable.

First, note that the third term, change in imports, has to be the largest in absolute value negative component so that the import shift would be the main cause of injury. However, in our case that term is positive independent of the assumptions about elasticity because the price increased over the analyzed period when imports fell. Indeed,

$\frac{1}{v}\left(-w_{D} e_{D} M\left(e_{M} \frac{\Delta P}{P}-\frac{\Delta M}{M}\right)\right)>0$ as $v<0,-w_{D} e_{D}<0, e_{M}>0, \frac{\Delta P}{P}>0,-\frac{\Delta M}{M}>0$.

Table 3 below presents the required information on consumption demand, domestic production, imports, and prices for the Ukrainian passenger car sector. Over the period 2008-2010, the price moderately increased, the consumption demand plummeted, and imports dropped. Due to data availability, the analysis is conducted for a four-digit code 8703 that covers also passenger cars that were not under safeguard investigation. However, the investigated products are about $80 \%$ of the passenger car market (Zerkalo Nedeli, 2012) and almost $100 \%$ of the domestically produced cars.

As discussed above, if the increased imports are the major cause of injury to the domestic industry, then the overall consumption should increase and price drop. The opposite happened in Ukraine: the imports dropped while price increased.

In order to make an assessment of the contribution of each injury factor, we need elasticity estimates. First, elasticity of export supply for Ukraine is estimated between 6 and 7 for HS codes 870322 and 870323 (Nicita et al., 2013). Table 4 present the outcome for a case where both domestic and foreign export supply elasticity equals 6 while domestic demand elasticity equals -1 as an example. Calculations reveal a negative shift in the domestic supply curve as the main 
Table 3. Passenger car market in Ukraine, 2008-2011

\begin{tabular}{|c|c|c|c|c|}
\hline & 2008 & 2009 & 2010 & 2011 \\
\hline Consumption, units & 623,000 & 162,300 & 162,600 & 220,000 \\
\hline Domestic production & 327,000 & 97,000 & 54,000 & 68,000 \\
\hline Import & 296,000 & 66,000 & 108,000 & 152,000 \\
\hline Export & 73,000 & 18,000 & 33,000 & 42,000 \\
\hline Import market share, per cent & 0.48 & 0.41 & 0.66 & 0.69 \\
\hline Average unit price, EUR & 13,965 & 14,295 & 16,605 & 16,364 \\
\hline
\end{tabular}

Source. Autoconsulting, available at http:/gazeta.zn.ua/ECONOMICS/programma_nadezhd_dlya_avtoproma. html.

cause of the injury to the domestic industry. Import supply does not appear to have caused any injury to the domestic industry. Although the weight of each factor varies with the elasticity estimates, the importance and signs of the effects are very robust for a variety of elasticity estimates applied. In particular, domestic supply shift is robustly the strongest injury factor and demand shift is the second injury factor. Finally, import shift is not a cause for injury, but rather a positive factor for domestic supply. Hence, the WTO Panel's decision is line with the economic assessment of the injury attribution.

\subsection{Alternative assessment of causality: case of downstream industry}

The passenger cars industry in Ukraine was focused on manufacturing and assembling cars for foreign brands under license agreements. The domestic industry needed contracts and orders from foreign brands in order to manufacture. This situation is rather different from a traditional domestic industry that can decide about its supply. Thus, the industry saw imports as a barrier to receiving foreign investments and stated that the safeguard measure should help to attract foreign companies to manufacture in Ukraine. A number of these brands manufacturing in Ukraine closed local production in or after 2009, opting for exporting the final product into Ukraine. Negative shock of the crisis combined with the more liberal import tariff could have triggered such decisions.

As more and more developing countries rely on offshoring, the policymakers will face a challenge of shielding the domestic industries when foreign firms re-shore or move to another location. Ukraine-Passenger Cars is an interesting case as it demonstrates the challenges faced by an FDI-reliant industry when several brands simultaneously stop operations, leaving factories empty.

Supply decomposition above revealed the domestic supply shift as the main cause of falling domestic production. But what are the factors shifting the Ukrainian car supply? The local companies were operating only thanks to the foreign investment for car assembly. This type of FDI is a direct substitute for car imports. The domestic firms compete with imports not only for car sales but also for ability to operate 
Table 4. Attribution of injury

\begin{tabular}{lccc}
\hline \hline $\begin{array}{l}\text { Percentage change in domestic } \\
\text { production }\end{array}$ & $\begin{array}{l}\text { Due to demand } \\
\text { shift }\end{array}$ & $\begin{array}{l}\text { Due to domestic supply } \\
\text { shift }\end{array}$ & $\begin{array}{l}\text { Due to import } \\
\text { shift }\end{array}$ \\
\hline$-83.5 \%$ & $-50 \%$ & $-99 \%$ & $+65 \%$ \\
\hline \hline
\end{tabular}

and assemble cars. So if the falling import tariffs due to WTO accession make exporting final goods more attractive relative to manufacturing in Ukraine, then it could be argued that the trade concessions have caused injury to the domestic market, and left the capacity underutilized and workers unemployed in a sudden manner.

Ukrainian domestic producers did not sustain injury due to the increased imports. But they could have sustained injury due to the trade concessions that made the FDI into domestic manufacturing unattractive. This distinction is very important as discussed by Sykes (2003). Sykes presents a comprehensive analysis of the GATT/WTO law regarding safeguard measures from an economic perspective. It discusses the inconsistencies of the formulation of the relevant rules in defining exogenous and endogenous factors. The paper argues that originally concession was the exogenous factor that could through increased imports cause injury to the industry (endogenous factors). However, later the understanding shifted to imports seen as exogenous factor that could cause injury, and the relationship to the concessions went away.

The original reference to trade concessions was made with regards to the GATT tariff cuts. However, the spirit of the original GATT concessions is comparable to the liberalization that the newly acceding WTO members undergo. From that perspective, the safeguard measures could be justified by demonstrating that trade concessions had a causal effect on market equilibrium that injured the domestic producers. And in this reasoning, the imports are not the problem per se but as an alternative to FDI. And as our brief analysis revealed, the domestic supply was the leading cause of injury. Therefore, one could argue that trade concessions related to the WTO accession had an unforeseen effect and caused injury to the domestic industry through the domestic supply rather than imports.

\section{Reassessing WTO Safeguards Law}

The Ukraine-Passenger Cars dispute offers a useful case study of the complexities of the economic analysis carried out by government agencies who administer domestic safeguards law, as well as the international legal review conducted by the WTO dispute settlement system. Beyond the specifics of this case, though, it also illustrates more generally some flaws in the safeguards system (and perhaps with trade remedies more broadly). 
A frequent criticism of the WTO's review of safeguards is that these measures are always found in violation of WTO obligations. Thus, it is suggested, in practice that the system does not allow safeguard measures and therefore does not function properly. ${ }^{14}$

This argument is technically true, if you focus only on claims against safeguards measures that have been brought to conclusion under the Safeguards Agreement. However, it misses some important context. While all WTO challenges under the Safeguards Agreement that have resulted in a ruling have led to a finding of violation, the vast majority of safeguards measures are never challenged. According to the WTO, from 1 January 1995 to 30 April 2015, there have been 147 safeguard measures imposed (WTO, 2015). In that same period, however, only 26 measures involving measures under the Safeguards Agreement were even challenged at the WTO (WorldTradeLaw.net, 2016), ${ }^{15}$ and only ten of these led to a dispute settlement ruling under the Safeguards Agreement. The practical reality, then, is that most safeguards measures are imposed without much of a fight from affected trading partners.

Nevertheless, it is true that when WTO Panels and the Appellate Body review safeguard measures, they always find flaws. But is there anything wrong with that?

On the one hand, it could be argued that WTO Panels and the Appellate Body are doing exactly what they are supposed to. Maybe the nit-picking they are doing is necessary as a constraint on investigating authorities. Without a serious check on their behavior, there would be a risk of biased findings by partial domestic government agencies. Thus, in this view, stringent oversight serves to keep the agencies in line.

As noted, there have been only ten measures found to violate the Safeguard Agreement. That is quite a small number in comparison to the total number of measures. And while all have found violations, keep in mind that over $90 \%$ of all WTO claims lead to findings of violation (WorldTradeLaw.net, 2016). The figure for safeguards is not significantly different from the total figure. For comparison, if you look at the SPS agreement, there have been nine dispute settlement rulings on particular SPS measures, all of which have been found in violation (WorldTradeLaw. net, 2016). ${ }^{16}$ Yet you do not often hear that the SPS agreement is not functioning properly. At the WTO, governments tend to only bring challenges that they are very likely to win. Thus, it should be no surprise that the safeguards measures which Members decided to challenge have been found in violation.

14 Bown (2002) discusses a related question of the relative unpopularity of safeguard measures.

15 It takes time for a WTO complaint to get started after a measure has been imposed, so it is not clear which time period should be used to gather precise data on the total number of safeguard measures that could be challenged. The period up to 30 April 2015 is just a rough approximation.

16 The Hormones Suspension cases are not included in this category, even though issues of SPS consistency were part of the dispute, as the primary claims focused on the legality of the US and Canadian suspension measures. 
In addition, if you move slightly beyond the Safeguards Agreement, there is a WTO case involving a safeguard measure imposed on Chinese tires under the special procedures of China's Accession Protocol, in which the WTO found no violation (Charnovitz and Hoekman, 2013). Thus, it is possible to impose a safeguard measure consistently with WTO rules.

On the other hand, critics of WTO dispute settlement review of safeguard measures feel that the standard being set is an impossible one to meet, as it appears determined to find some fault in every case. It is unclear what is required of the domestic government agencies, the critics argue, and there are often some requirements developed by Panels and the Appellate Body and imposed on investigating authorities that lead to violations which could not have been anticipated. Strict is fine, these folks say, but the review actually being conducted goes too far.

In the face of this controversy, it is worth considering the options going forward for how best to deal with safeguard measures in international trade law and litigation. If we were to do something about safeguards at the WTO, what could be done? One approach would be to consider each of the main Safeguards Agreement obligations in the context of a broad review of the agreement by all WTO members, taking into account the jurisprudence so far. How should the causation analysis work? What kind of link should there be between increased imports and injury? Do we really need an unforeseen developments requirement? However, any ambitious review plan of this sort might be unrealistic given the realities of WTO negotiations these days. As part of the Doha round, WTO members have been reviewing anti-dumping and countervailing duties, but have not come close to reaching agreement. It is not clear why safeguards would fare any better.

Perhaps a simpler and more feasible approach would be to adjust the standard of review applied by Panels. That standard was expressed this way by the UkrainePassenger Cars Panel:

7.27. In case there is no reasoned and adequate explanation in the published report to support the competent authorities' determinations, 'the panel has no option but to find that the competent authority has not performed the analysis correctly'. This notably implies that reasoning, analysis and demonstrations provided after publication of the report - i.e. ex post explanations - are irrelevant and cannot be relied upon to remedy any deficiencies of the competent authorities' determinations.

The standard of review is a judicial creation, so it does not require an amendment to the Safeguards Agreement to change it (although the change could be carried out this way). All it would take is recognition by Panels and the Appellate Body that a new approach is needed. There are two options in this regard. First, the standard of review itself could be changed, perhaps along the lines of some of the AD Agreement standards that, on their face at least, could be taken to offer more deference to domestic authorities. Second, the standard of review language noted above could be applied more flexibly, giving investigating authorities more 
leeway. For example, in the Ukraine-Passenger Cars case, the Panel could have found that the end-point-to-end-point analysis carried out by the investigating authority was good enough. 'Reasoned and adequate' has a lot of flexibility embedded it. Panels looking to be more deferential to domestic authorities could use this flexibility to find that imperfect reasoning by domestic authorities is good enough to meet the Safeguards Agreement obligations.

Finally, to take a more radical route, consider the nature of the exercise of applying safeguards. A domestic government agency conducts an examination of whether imports are harming a domestic industry. While foreign interests are represented in the preceding, and there is the possibility of domestic judicial review, there is nonetheless a concern that the examination will not be carried out fairly. To deal with this worry, there is a separate international review process at the WTO. However, the review is not a de novo one, but rather one that scrutinizes the domestic agencies' reasoning.

This process takes a great deal of time. In this case, domestic authorities initiated the investigation on 30 June 2011 with the measure imposed in April of 2013. At the WTO, the consultations request was filed on 30 October 2013, with DSB adoption taking place on 20 July 2015. Thus, the process takes a long time (here, four years in total), and leads to results which seem to leave many people unhappy. Perhaps there is a better way.

If the goal is to ensure a neutral determination of whether a safeguard measure is justified, we could consider setting up a special international tribunal to make the initial decision on imposition of the measure. Thus, instead of the domestic industry petitioning a domestic government agency with its claims of injury, it would go straight to the WTO. In this scenario, the WTO tribunal would not be reviewing the government decision, but rather conducting a de novo review of whether increased imports, serious injury, and causation occurred.

There are several benefits of this approach. First, it would save the time and expense of the WTO challenge. Having built-in international review at the initial stage, the long WTO litigation process could be avoided.

Second, it removes the worry of nationalistic bias. Rather than use international oversight of domestic government action, it simply eliminates that government action entirely, and thus the potential for bias is gone.

Third, it reconceives the WTO's role in relation to domestic protectionism. Instead of the WTO always being the international organization that thwarts domestic protectionism, to the dismay of many industry and labor groups, the WTO could now authorize some protectionism. Obviously, from a policy perspective, this result is a negative. We would be better off with less protectionism, not more. But politically, we know there will always be some protectionism, and this might be a better approach to managing it.

Fourth, the added efficiency of one tribunal to handle these cases, rather than dozens of national agencies, would be enormous. 


\section{Conclusions}

After a surge of WTO dispute settlement reports on safeguards measures from 1999-2003, the numbers of have dwindled considerably. There was one in 2012, and now the Ukraine-Passenger Cars case in 2015. There is one more case in the pipeline.

The limited number of cases probably means any issues related to safeguards adjudication at the WTO will not get much attention anytime soon. The initial surge of safeguards disputes brought lots of attention; the subsequent decline in these cases led to that attention being shifted elsewhere.

Nevertheless, each new Panel finding offers an opportunity to reassess both the economics of safeguards and their international judicial review at the WTO. This paper has tried to offer economic insights about this particular case, and broader suggestions about the role of the WTO in these matters.

This case also highlights the problems that developing countries face in the application of WTO rules. Ukraine's handling of the safeguard investigation in this case appears to have been driven more by domestic political considerations than the discipline required by the rules-based WTO process. To a large extent, this is driven by the lack of understanding of the complexities of such investigations. Both the domestic industry association and government representatives were stating that the goal was to attract car manufacturers to assemble cars in Ukraine, in one of the largest markets in Europe, a significant growth potential. The domestic industry and policy-makers were facing a drastic drop in sales, and withdrawal of investment after a relatively long period of stable growth. However, the domestic parties were not fully aware of the available tools, as well as costs and benefits of these tools. Earlier safeguard disputes have already shown that developing countries might not fully internalize the complexities and consequences of the obligations they undertake, e.g. Bown and Wu (2014) analyze the case of Dominican Republic's safeguard measure. Thus, our findings suggest a need for more capacity building to help developing countries better use of WTO-sanctioned investment and trade policy tools.

\section{References}

AUTO-Consulting (2012a), 'Решение о введении спецпошлин на иномарки будет принимать Петр Порошенко', http:/www.autoconsulting.ua/article.php?sid=23296 (accessed 1 June 2016).

(2012b), 'Спецпошлины на иномарки. Кому это выгодно?', http://www.autoconsulting.com.ua/ article.php?sid=23544 (accessed 1 June 2016).

(2012c), 'Петр Порошенко: В Украине будут введены спецпошлины на иномарки (обновлено)', http://www.autoconsulting.ua/article.php?sid=23970 (accessed 1 June 2016).

— $(2012 \mathrm{~d})$, 'Виктор Янукович недоволен инициативой Порошенко о повышении пошлин на иномарки', http://www.autoconsulting.ua/article.php?sid=23987 (accessed 1 June 2016).

— (2009a), 'Автомобильный рынок Украины. Итоги 2008 года и прогноз на 1 квартал 2009 года', http://www.autoconsulting.ua/article.php?sid=11934 (accessed 1 June 2016). 
(2009b), 'Что будет с украинским авторынком в 2010 году? Прогноз от Группы компаний «АИС»', http://autoconsulting.com.ua/article.php?sid=15101 (accessed 1 June 2016).

Bown, C. P. (2002), 'Why Are Safeguards under the WTO so Unpopular?', World Trade Review, 1(1): 47-62.

Bown, C. P. and R. McCulloch (2003), 'Nondiscrimination and the WTO Agreement on Safeguards', World Trade Review, 2(3): 327-348.

Bown, C. P. and M. Wu (2014), 'Safeguards and the Perils of Preferential Trade Agreements: Dominican Republic-Safeguard Measures', World Trade Review, 13(2): 179-227.

Charnovitz, S. and B. Hoekman (2013), 'US-Tyres: Upholding a WTO Accession Contract - Imposing Pain for Little Gain', World Trade Review, 12(2): 273-296.

CMS Law-Now (2009), 'Ukraine: 13\% Import Duty Mark-Up', http://www.law-now.com/ealerts/2009/ 02/ukraine-13-import-duty-markup?cc_lang=en (accessed 1 June 2016).

Ernst and Young (2016), 'The Central and Eastern European Automotive Market - Ukraine', http://www. ey.com/GL/en/Industries/Automotive/The-Central-and-Eastern-European-automotive-market--Country-profile--Ukraine (accessed 1 June 2016).

Focus (2008), ‘Автомобильные аппетиты растут', https:/focus.ua/money/16098/ (2008) (accessed 1 June 2016).

Golovnev Sergii (2014), 'Бізнес нового президента', The Insider, http:/www.theinsider.ua/business/ $538796 \mathrm{bfc} 96 \mathrm{ca} /$ (accessed 1 June 2016).

HumanProgress.org (2014), 'Passenger Cars', http://www.humanprogress.org/f1/2385 (accessed 1 June 2016).

Irwin, D. A. (2003), 'Causing Problems? The WTO Review of Causation and Injury Attribution in US Section 201 Cases', World Trade Review, 2(3): 297-325.

Kelly, K. (1988), 'The Analysis of Causality in Escape Clause Cases', Journal of Industrial Economics, 37: 187-207.

Nicita, A., M. Olarreaga, and P. Silva (2013), 'Cooperation in WTO's Tariff Waters', CEPR Discussion Paper No. 9529.

Sykes, A. O. (2003), 'The Safeguards Mess: A Critique of WTO Jurisprudence', World Trade Review, 2(3): 261-295.

Ukrayinska Pravda (2003), ‘Эхо торговой войны’, http://www.pravda.com.ua/rus/news/2003/02/3/ 4371505/ (accessed 1 June 2016).

World Bank (2015), 'World Development Indicators GDP, PPP (constant 2011 international \$)', http:// data.worldbank.org/indicator/NY.GDP.MKTP.PP.KD (accessed 1 June 2016).

World Trade Organization (WTO) (2015), 'Statistics on Safeguard Measures', https://www.wto.org/ english/tratop_e/safeg_e/safeg_e.htm\#statistics (accessed 1 June 2016).

_ (2016), 'Trade Policy Review: Ukraine, Executive Summary', https:/www.wto.org/english/tratop_e/ tpr_e/tp434_e.htm (accessed 1 June 2016).

WorldTradeLaw.net (2016), Dispute Settlement Statistics and Tables, http:/www.worldtradelaw.net/ static.php?type $=$ dsc\&page $=$ stats (accessed 1 June 2016).

Zerkalo Nedeli (2012), ‘Иномарки снова будут дорожать: Украина введет пошлины на импорт авто’, http:// zn.ua/ECONOMICS/inomarki_snova_budut_dorozhat_ukraina_vvedet_poshliny_na_import_avto. html (accessed 1 June 2016). 